\title{
Analisis Karakteristik Pulp Campuran Tandan Kosong Kelapa Sawit dan Pelepah Pisang dengan Pelarut NaOH
}

\author{
Sari Rizky Amelia*1, Muhammad Yerizam², Erwana Dewi ${ }^{3}$ \\ ${ }^{1,2,3}$ Program Studi Teknologi Kimia Industri, Jurusan Teknik Kimia \\ Politeknik Negeri Sriwijaya, Indonesia. \\ Email: ${ }^{1}$ saririzkya@gmail.com
}

\begin{abstract}
Abstrak
Pulp merupakan hasil dari proses peleburan kayu atau bahan berserat lainnya baik secara mekanis, kimia, maupun semikimia sebagai bahan dasar pembuatan kertas dan turunan selulosa lainnya. Bahan pembuat pulp dari campuran Tandan kosong kelapa sawit (TKKS) yang kandungan selulosanya 45,95\% serta pelepah pisang yang kandungan selulosanya sekitar 63-64\%. Penelitian ini bertujuan untuk mengetahui kondisi optimum pada proses pembuatan pulp dengan memvariasikan waktu pemasakan yakni 75, 90, 105, 120 dan 135 menit. Selain itu juga memvariasikan konsentrasi larutan $\mathrm{NaOH}$ dengan variasi $7 \%$ dan $9 \%$, serta variasi bahan baku (TKKS:pelepah pisang) yakni 40:60; 50:50; 60:40. Sehingga pada penelitian ini didapatkan kondisi optimumnya yakni pada rasio 40:60, dengan konsentrasi 9\% dan waktu pemasakan selama 120 menit didapatkan nilai kadar lignin $11,21 \%$ dan kadar selulosa $68,94 \%$.
\end{abstract}

Kata kunci: lignin, pelepah pisang, pulp, selulosa, TKKS.

\section{Analysis of Characteristics of Pulp Mixture of Empty Fruit Bunches of Palm Oil and Banana Midrib with $\mathrm{NaOH}$ Solvent}

\begin{abstract}
Pulp is the result of the smelting process of wood or other fibrous materials either mechanically, chemically, or semi-chemically as the basic material for making paper and other cellulose derivatives. The pulp is made from a mixture of oil palm empty fruit bunches or TKKS which contains $45.95 \%$ cellulose and banana midrib which contains $63-64 \%$ cellulose. This study aims to determine the optimum conditions in the pulping process by varying the cooking time, namely 75, 90, 105, 120 and 135 minutes. In addition, it also varies the concentration of $\mathrm{NaOH}$ solution with variations of $7 \%$ and $9 \%$, as well as variations of raw materials (TKKS: banana midrib) namely 40:60; 50:50; 60:40. So that in this study the optimum conditions were obtained, namely at a ratio of 40:60, with a concentration of $9 \%$ and a cooking time of 120 minutes, the lignin content value was $11.21 \%$ and the cellulose content was $68.94 \%$.
\end{abstract}

Keywords: banana midrib, cellulose, lignin, TKKS.

\section{PENDAHULUAN}

Satu ton kelapa sawit terdiri dari 230-250 kg Tandan Kosong Kelapa Sawit, cangkang sebanyak $65 \mathrm{~kg}$, serat sebanyak 130-150kg dan biji sebanyak 55-60 kg. Hal ini mengakibatkan bertambahnya limbah dan menimbulkan permasalahan baru akibat dari bertambahnya limbah padat yang dihasilkan dari pabrik pengelolaan minyak sawit [1].

Salah satu produk sampingan yang berupa padatan dari industri pengolahan kelapa sawit yakni Tandan Kosong Kelapa Sawit (TKKS)[2]. Tandan kosong kelapa sawit (TKKS) merupakan limbah padat yang dihasilkan dari proses pembuatan minyak kelapa sawit dan mengandung selulosa sebanyak 45,95\%, kadar abu sebanyak 1,23\%, hemiselulosa sebanyak 22,84\%, kadar air sebanyak 3,74\% dan lignin sebanyak 16,49\%[3]. Selain TKKS, tanaman lain yang belum dimanfaatkan secara optimal padahal mengandung yang cukup tinggi yakni pelepah pisang. Pada pelepah pisang densitasnya sebesar 1,35 gr/ $\mathrm{cm}^{3}$, selulosa sebanyak $63-64 \%$, hemiselulosa sebanyak $20 \%$, lignin sebanyak 5\%, kekuatan Tarik rata-rata sebesar 600 Mpa, modulus tarik ratarata sebesar $17,85 \mathrm{Gpa}$, angka pertambahan panjangnya $3,36 \%$, diameter serat $5,8 \mu \mathrm{m}$, serta panjang serat $30,9240 \mathrm{~cm}[4]$. 
Beberapa industri pengolahan kelapa sawit telah memanfaatkan TKKS sebagai bahan pembuatan pupuk kompos. Namun masih banyak yang membuang begitu saja ataupun hanya dibakar sehingga dapat mencemari lingkungan. Padahal di dalam TKKS terdapat kandungan selulosa yang tinggi sehingga dapat dikembangkan lagi menjadi bahan baku bagi produk yang berbasis selulosa seperti pulp. Hal ini juga didukung fakta bahwa industri pulp saat ini mengalami kesulitan dalam mendapatkan bahan baku serupa. sedangkan pelepah pisang di dunia industri termasuk ke dalam katagori limbah pertanian yang pemanfaatannya belum optimal padahal memiliki kandungan selulosa yang tinggi di dalamnya.

Kedua bahan ini belum dimanfaatkan secara optimal agar memiliki nilai ekonomis yang lebih tinggi sehingga untuk menambah nilai ekonomisnya kedua bahan ini akan dicampur dan dibuat menjadi pulp.

Pulp merupakan hasil dari proses peleburan kayu atau bahan berserat lainnya baik secara mekanis, kimia, maupun semikimia sebagai bahan dasar pembuatan kertas dan turunan selulosa lainnya seperti sutera rayon dan selofan. Pulp terdiri dari serat-serat, seperti selulosa dan hemiselulosa yang merupakan bahan baku pembuatan kertas[5].

Pulp dapat dibuat dari senyawa-senyawa kimia turunan selulosa, sehingga pulp dapat dibuat dari berbagai jenis kayu dan bambu serta rumput-rumputan dengan berbagai proses pembuatan, yakni secara mekanis, semikimia, dan kimia[5].

Pembuatan pulp memiliki tujuan utama, yakni untuk melepaskan serat-serat baik dengan cara kimia, mekanis ataupun kombinasi antara kimia dan mekanis. Dari setiap proses pembuatan pulp yang berbeda maka menghasilkan karakteristik pulp yang berbeda pula, sehingga jenis dari proses pembuatan pulp tergantung pada spesifikasi serat bahan baku dan produk yang diinginkan. Klasifikasi sifat-sifat kertas biasanya terdiri dari sifat fisik, sifat kimia, sifat optik, sifat elektrik dan sifat mikroskofis. Sifat fisik meliputi uji ketahan tarik, lipat, sobek, retak, kekasaran, kekuatan, berat dan kehalusan serta uji ketebalan. Untuk sifat optik meliputi warna. uji opasitas dan derajat putih kilap. Sedangkan sifat elektrik meliputi sifat konduksi dan induksi. Serta pada sifat kimia untuk menentukan kadar selulosa, pentosa, kadar abu, bahan pengisi, viskositas, tembaga, serta $\mathrm{pH}$ dan kadar air, sedangkan sifat mikrokofis terdiri dari penentuan jenis serat, analisa kualitatif bahan pengisi dan uji noda[6].

Faktor yang mempengaruhi pembuatan pulp, diantaranya adalah konsentrasi pelarut, rasio cairan masak terhadap bahan baku, temperature pemasakan, waktu pemasakan, ukuran bahan baku dan kecepatan pengadukan[7].

Dalam penelitian ini variasi yang digunakan adalah rasio umpan, waktu pemasakan dan konsentrasi pelarut. Hal ini bertujuan untuk memperoleh produk dengan kadar lignin dan selulosa yang memenuhi Standar Nasional Indonesia dan mendapatkan komposisi campuran tandan kosong kelapa sawit dan pelepah pisang, waktu pemasakan serta konsentrasi $\mathrm{NaOH}$ yang digunakan sehingga mendapatkan pulp yang optimum dari campuran tandan kosong kelapa sawit dan pelepah pisang.

\section{METODE PENELITIAN}

\subsection{Waktu dan Tempat}

Penelitian ini dilaksanakan pada bulan Maret-Juli 2021 di Laboratorium Kimia Analisis Dasar, Jurusan Teknik Kimia Politeknik Negeri Sriwijaya. Penelitian ini dilakukan mulai dari pukul 08.00-16.00 WIB.

\subsection{Alat dan Bahan}

Adapun alat yang digunakan dalam penelitian ini adalah timbangan analitis, oven, ayakan, corong gelas, batang pengaduk, spatula, beaker glass, waterbath, kaca arloji, spatula, crussible, oven, pipet ukur, bola karet dan seperangkat alat digester.

Bahan yang digunakan dalam penelitian ini adalah tandan kosong kelapa sawit yang diambil dari PT. DSAP Palembang, pelepah pisang, $\mathrm{NaOH}, \mathrm{H}_{2} \mathrm{SO}_{4}, \mathrm{CH}_{3} \mathrm{COOH}$, aquadest, kertas saring serta kertas $\mathrm{pH}$.

\subsection{Preparasi Sample}

Persiapan yang dilakukan untuk bahan baku pembuatan pulp dengan mencuci TKKS dan pelepah pisang kemudian dijemur hingga kering dan dihaluskan TKKS dan pelepah pisang hingga 80 mesh.

\subsection{Proses Pemasakan Pulp}

Membuat larutan $\mathrm{NaOH}$ sebanyak $3636 \mathrm{ml}$ dengan konsentrasi 7\% dan 9\%, menimbang TKKS dan pelepah pisang sebanyak 363 gr dengan variasi rasio 40:60, 50:50 dan 60:40. Mencampurkan bahan dengan pelarut 
$\mathrm{NaOH}$ ke dalam digester, kemudian memasak campuran sample di dalam digester dengan kecepatan pengadukan $95 \mathrm{rpm}$, temperature $120^{\circ} \mathrm{C}$. Waktu pemasakan yang digunakan yaitu 75 menit, 90 menit, 120 menit, 105 menit dan 135 menit, Setelah proses pemasakan, mendinginkan sampel lalu menyaring dan juga mencuci hasil pemasakan sehingga dapat memisahkan sisa hasil pemasakan yang berupa lindi hitam (black liquor) dan raw pulp. Selain itu penyaringan juga dilakukan untuk memisahkan kotoran pada pulp hasil pemasakan. Setelah itu, menganalisa kadar lignin dan selulosa pada pulp.

\subsection{Analisa Kadar Selulosa}

Pengujian kadar selulosa sesuai dengan SNI-0444 yakni : kertas saring dipanaskan dalam oven pada temperatur $105{ }^{\circ} \mathrm{C}$ kemudian menimbangnya hingga beratnya konstan, menimbang sample sebanyak 3 gram, kemudian memindahkannya ke beaker gelas $250 \mathrm{ml}$, dibasahkan menggunakan $15 \mathrm{ml} \mathrm{NaOH} \mathrm{17,5 \%} \mathrm{dan}$ mengaduk dengan pegaduk selama 1 menit, lalu menambahkan $10 \mathrm{ml} \mathrm{NaOH} \mathrm{17,5 \%} \mathrm{dan} \mathrm{mengaduk} \mathrm{selama} 15$ detik, mendiamkan selama 3 menit, kemudian menambahkan kembali $10 \mathrm{ml} \mathrm{NaOH} \mathrm{17,5 \%} \mathrm{(3x)} \mathrm{setiap} \mathrm{2,5,} \mathrm{dan} 7$ menit. Mendiamkan selama 30 menit, kemudian menambahkan $100 \mathrm{ml}$ aquadest dan mendiamkan selama 30 menit, menuang campuran ke dalam corong yang dilengkapi kertas saring, mencuci dengan 50 ml aquadest sebanyak 5 kali, mencuci endapan kembali dengan $400 \mathrm{ml}$ aquadest, menambahkan asam asetat $2 \mathrm{~N}$ dan mengaduk selama 15 menit .

$$
\% \text { selulosa }=\frac{\text { berat endapan selulosa }}{\text { berat sample awal }} \times 100 \%
$$

\subsection{Analisa Kadar Lignin}

Pengujian kadar lignin sesuai dengan SNI-0445, yakni : sampel kering ditimbang sebanyak 2 gram, dimasukkan kedalam gelas kimia dan ditambahkan sedikit demi sedikit asam sulfat $72 \%$ sambil diaduk sampai contoh terendam, gelas kimia ditutupi dan dijaga temperaturnta pada suhu $20^{\circ} \mathrm{C}$ selama 2 jam kemudian ditambahkan $40 \mathrm{ml}$ aquades kedalam gelas kimia. Kemudian larutan dididihkan selama 4 jam dalam gelas kimia. Mendiamkan campuran hingga endapan lignin mengendap kemudian menyaringnya sehingga mendapatkan lignin. Mencuci lignin yang didapat dengan air panas kemudian mengeringkannya di dalam oven pada $105^{\circ} \mathrm{C}$, kemudian ditimbang sampai beratnya konstan.

$$
\% \text { Kadar Lignin }=\frac{\text { berat endapan lignin }}{\text { berat sample awal }} \times 100 \%
$$

\section{HASIL DAN PEMBAHASAN}

\subsection{Analisa Kadar Selulosa}

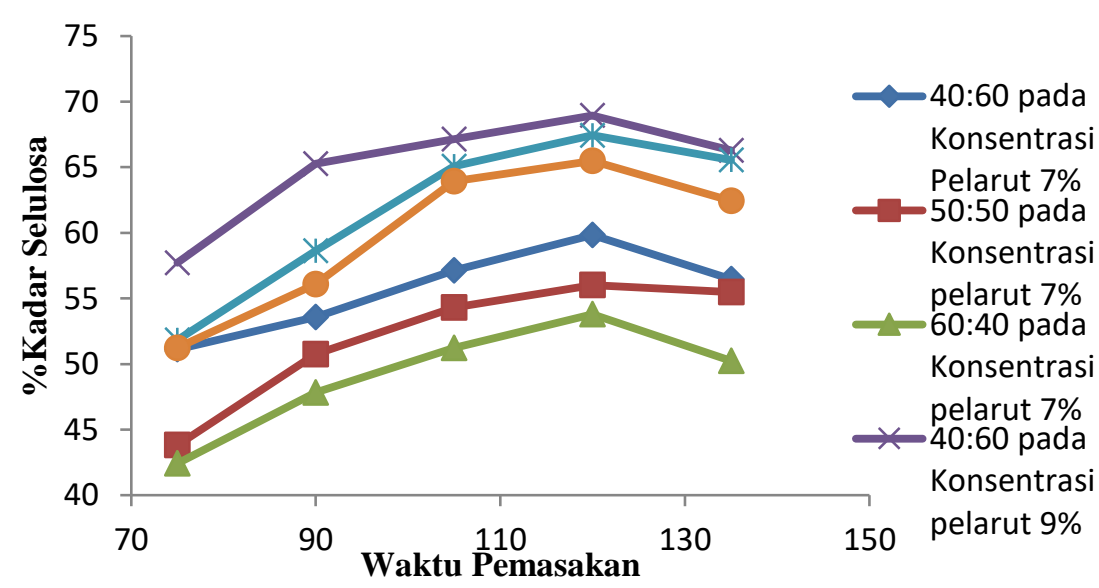

Gambar 1. Grafik Pengaruh Waktu terhadap Kadar Selulosa

Kadar selulosa yang didapatkan dari hasil penelitian berkisar antara 42-69\%. Dari Gambar 1. terlihat bahwa semakin lama waktu pemasakan pulp maka kadar selulosa pulp akan semakin meningkat hingga akhirnya menurun kembali. Kenaikan tersebut karena semakin lama waktu pemasakan membuat lignin sebagai pengikat 
selulosa akan terpisah sehingga konsentrasi selulosa semakin besar, namun terjadi penurunan karena selulosa terdegradasi dan menyebabkan penurunan kadar selulosa pada pulp.

Dari grafik dapat diketahui bahwa kadar selulosa terkecil berada pada perbandingan 60:40 dan kadar selulosa terbesar berada pada perbandingan 40:60, sehingga dapat diketahui bahwa semakin banyak penambahan pelepah pisang dapat meningkatkan kadar selulosa pada pulp yang dihasilkan. Hal ini juga dipengaruhi oleh kadar selulosa pada pelepah pisang lebih besar dibanding kadar selulosa pada tandan kosong kelapa sawit.

Pada konsentrasi $7 \%$ yakni $59.83 \%$ dan pada konsentrasi $\mathrm{NaOH} 9 \%$ kadar selulosanya sebesar $68.94 \%$. Dari data tersebut dapat diketahui bahwa dengan penambahan konsentrasi maka kadar selulosa yang dihasilkan meningkat pula, hal ini terjadi karena ion-ion $\mathrm{OH}^{-}$terlarut oleh larutan $\mathrm{NaOH}$ sehingga ikatan dari struktur lignin terputus.

\subsection{Analisa Kadar Lignin}

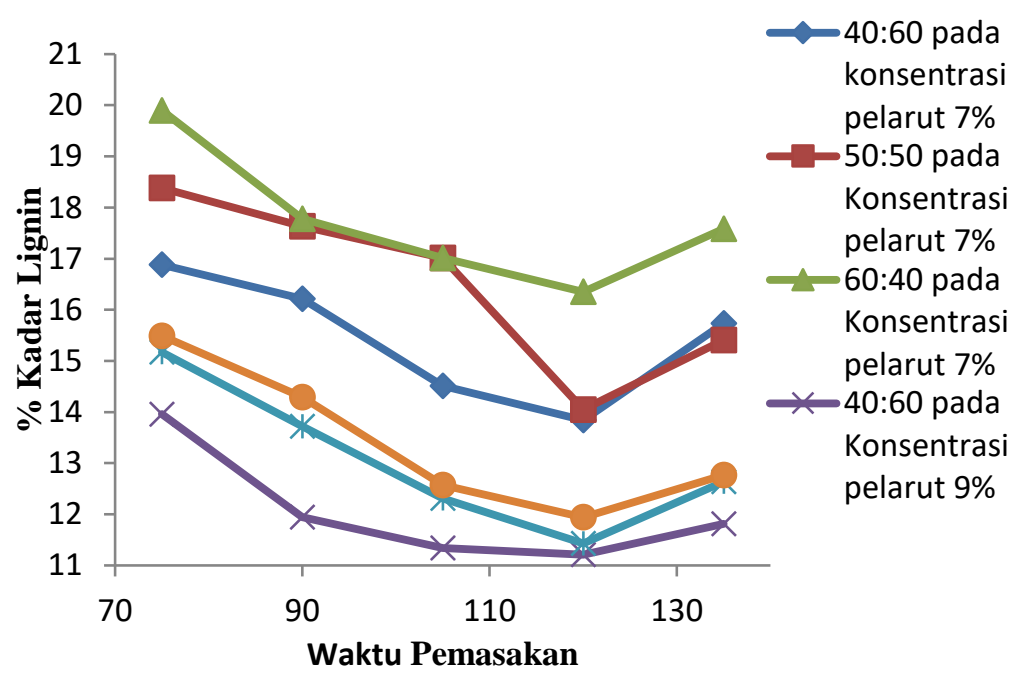

Gambar 2. Grafik Pengaruh Waktu terhadap Kadar Lignin

Kandungan lignin pada pulp cenderung mengalami penurunan seiring dengan semakin lamanya waktu masak, akan tetapi pada saat waktu pemasakan 135 menit kadar lignin mengalami kenaikan. Kadar lignin terendah pada saat waktu pemasakan 120 menit yaitu sebesar $11.21 \%$, dan kadar lignin tertinggi pada saat waktu pemasakan 75 menit yaitu sebesar 19.9\%. kadar lignin mengalami penurunan disebabkan karena pada waktu pemasakan tersebut lignin terpisah dari selulosa namun jika terlalu lama maka kadar lignin meningkat.

Penggunaan pelarut $\mathrm{NaOH}$ dengan konsentrasi $7 \%$ didapatkan kadar lignin dengan rasio umpan tandan kosong kelapa sawit : pelepah pisang berturut-turut 40:60, 50:50, 60:40 yakni $13.84 \%, 14.05 \%$ dan $16.35 \%$ sedangkan pada penggunaan pelarut $\mathrm{NaOH} 9 \%$ kadar ligninnya berturut-turut sebesar $11.21 \%, 11.43 \%$ dan 11.94\%. dari data tersebut dapat diketahui bahwa kadar lignin terkecil berada pada perbandingan 40:60 dan kadar lignin terbesar pada perbandingan 60:40. Sehingga dapat dikatakan bahwa semakin banyak pelepah pisang dapat menurunkan nilai lignin yang terkandung.

Pada penelitian ini menggunakan konsentrasi $\mathrm{NaOH} 7 \%$ dan 9\%, dimana pada konsentrasi $7 \%$ nilai ligninnya $13,84 \%$ dan pada konsentrasi $9 \%$ yakni $11.21 \%$, hal ini menandakan bahwa semakin tinggi konsentrasi maka dapat menurunkan kadar lignin yang disebabkan oleh bereaksinya lignoselulosa sehingga ikatan lignin terputus dan kadarnya menurun.

\section{KESIMPULAN}

Berdasarkan penelitian yang telah dilakukan maka dapat diketahui bahwa kadar selulosa dan lignin yang didapatkan berturut-turut 68,94\% dan 11,21\%, sehingga memenuhi kriteria SNI-7274 serta rasio umpan tandan kosong kelapa sawit dan pelepah pisang, waktu pemasakan dan konsentrasi pelarut untuk mendapatkan pulp yang memenuhi SNI beturut-turut adalah 40:60, 120 menit dan 9\%.

\section{DAFTAR PUSTAKA}

[1] Y. Fauzi, Kelapa Sawit : Budi Daya, Pemanfaatan Hasil dan Limbah, Analisis Usaha dan Pemasaran. Jakarta, Indonesia: Penebar Swadaya, 2008. 
[2] D. Siahaan, E. Nuryanto, J. Elisabeth, L. Erningpraja, P. L. Tobing, P. M. Naibaho, T. Haryati D. Darnoko, "Teknologi pengolahan kelapa sawit dan produk turunannya," Pusat Penelitian Kelapa Sawit, Medan.[Indonesian], 2002.

[3] K. Muzakhar, S. A. S. N. Azizah, "Skrining Bakteri Selulolitik Asal Vermicomposting Tandan Kosong Kelapa Sawit," Berkala Sainstek, vol. 2, 2014.

[4] O. Nawansih, S. H. Zulferiyenni, "Proses Pembuatan Pulp Berbasis Ampas Tebu: Batang Pisang dengan Metode Acetosolve," Jurnal Universitas Lampung, vol. 14, 2009.

[5] D. Satriawan, A. H. Surest, "Pembuatan Pulp dari Batang Rosella dengan Proses Soda (Konsentrasi NaOH, Temperatur Pemasakan dan Lama Pemasakan)," Jurusan Teknik Kimia Fakultas Teknik Universitas Sriwijaya, vol. 7, Agustus 2010.

[6] M. Sembiring, P. Sinuhaji, D. F. B. Tarigan, "Pembuatan dan Karakterisasi Kertas dengan Bahan Baku Tandan Kosong Kelapa Sawit," Jurnal Fisika FMIPA Universitas Sumatera Utara, 2013.

[7] Dandy, W. A. T. K. Dewi, "Pengaruh Konsentrasi NaOH, Temperatur Pemasakan, dan Lama Pemasakan pada Pembuatan Pulp dari Batang Rami dengan Proses Soda," Jurusan Teknik Kimia Fakultas Teknik Universitas Sriwijaya, vol. 17, April 2010. 